\title{
Characterization of bacteriophage BFK20 from Brevibacterium flavum
}

\author{
Michael Koptides, ImRICH BaRÁK, MaRTa Šišová, Edita Baloghová, \\ JANA UgORČAKOVÁ and JOZEF TIMKO*
}

Institute of Molecular Biology, Slovak Academy of Sciences, 84251 Bratislava, Czech and Slovak Federal Republic

(Received 23 March 1992; accepted 2 April 1992)

\begin{abstract}
Bacteriophage BFK20 was isolated from a Brevibacterium flavum strain that had become contaminated during industrial fermentation. BFK20 has a polyhedral head $50 \mathrm{~nm}$ wide and a non-contractile tail $200 \mathrm{~nm}$ long and $10 \mathrm{~nm}$ in diameter. The genome of this bacteriophage consists of a linear double stranded DNA molecule of 44$45 \mathrm{~kb}$ with cohesive ends. The capsid of phage BFK20 contains nine polypeptides with molecular masses from 22.0108.0 kDa. BFK20 DNA was used as a donor for fragments carrying promoters and transcription-terminators.
\end{abstract}

\section{Introduction}

Brevibacterium flavum and related bacteria ("brevibacteria') are Gram-positive, coryneform, glutamic-acidproducing bacteria that are very important for industrial production of various L-amino acids and flavour enhancing nucleotides (Yoshinaga \& Nakamori, 1983).

The existence of bacteriophages in corynebacteria has been known for many years (Hongo et al., 1972; Ozaki et al., 1984; Pátek et al., 1985; Trautwetter et al., 1987a, b), and brevibacteria are susceptible to a number of these phages. Although bacteriophages are useful tools for studying the biology of their hosts only a few have been used for this purpose in brevibacteria. A cosmid vector that can be packaged in vivo has been developed (Miwa $e t$ al., 1985), but phage cloning vectors have not yet been described and little is known about the life cycles of these bacteriophages.

We describe in this paper the characteristics of bacteriophage BFK 20 and the isolation of fragments of phage DNA with promoter activity using the promoter probe vector pJUP05 (Barák et al., 1990). We also describe the isolation of a transcription-terminator from phage BFK20 DNA.

\section{Methods}

Bacterial strains, bacteriophage and plasmid. The following bacterial strains were used: Brevibacterium lactofermentum BLOB (Santamaria et al., 1984), Brevibacterium flavum ATCC 21474, Brevibacterium flavum ATCC 21127, Corynebacterium glutamicum ATCC 13032, Corynebacterium glutamicum RM3 (restriction modification mutant) and Brevi-

* Author for correspondence. Tel. 7378 2224; fax 7372316 . bacterium flavum CCM 251. Phage BFK20 was isolated from a Brevibacterium flavum strain that had become contaminated during industrial fermentation. The promoter probe vector pJUP05 (Barák et al., 1990), Escherichia coli HB101 (Boyer \& Roulland-Dussoix, 1969) and $C$. glutamicum RM3 were used in DNA cloning experiments.

Media and cultures. LB medium (Maniatis et al., 1982) was used as a medium for $E$. coli and strains of brevibacteria. BHI medium (Yeh et al., 1986) was used as a medium for protoplasts of brevibacteria.

Ampicillin (Ap, $50 \mathrm{mg} \mathrm{l}^{-1}$ ), chloramphenicol $\left(\mathrm{Cm}, 10 \mathrm{mg} \mathrm{l}^{-1}\right)$ and kanamycin ( $\mathrm{Km}$, from 10 to $1000 \mathrm{mg}^{-1}$ ) were used for $E$. coli ; and $\mathrm{Cm}$ $\left(8 \mathrm{mg} \mathrm{l}^{-1}\right.$ ) and $\mathrm{Km}$ (from 10 to $1000 \mathrm{mg} \mathrm{l}^{-1}$ ) for strains of brevibacteria, which were grown under aerobic conditions at $37^{\circ} \mathrm{C}$ and $30^{\circ} \mathrm{C}$, respectively. LB medium supplemented with $5 \mathrm{~g} \mathrm{NaCl} \mathrm{l}^{-1}, 2 \mathrm{~g}$ glucose $1^{-1}$ and $10 \mathrm{mM}-\mathrm{MgSO}_{4}$ (LBS medium) (Trautwetter et al., 1987a) was used as a liquid medium for preparation of phage lysates. Solid media were prepared by adding $1.5 \%(\mathrm{w} / \mathrm{v})$ agar (Difco) to the liquid media: $0.6 \%$ agar was added to the liquid media for preparation of the soft overlay.

Phage titration and lytic spectrum. These were determined by the method described by Adams (1959). The precise titre was determined by mixing appropriate amounts of bacteria and phages in soft agar.

Preparation and purification of phage lysates. B. flavum CCM 251 was grown to an $\mathrm{OD}_{570}$ of $0.3-0.5 \mathrm{in} 100 \mathrm{ml} \mathrm{LB}$ and infected with phage BFK20 in the presence of $10 \mathrm{mM}-\mathrm{MgSO}_{4}$. After incubating for $30 \mathrm{~min}$ at $30^{\circ} \mathrm{C}$ without shaking, the infected culture was diluted in $900 \mathrm{ml} \mathrm{LB}$ supplemented with $10 \mathrm{~mm}-\mathrm{MgSO}_{4}$ and then incubated at $30^{\circ} \mathrm{C}$ with shaking until complete lysis occurred, generally for $6 \mathrm{~h}$. The phages were concentrated by the method of Yamamoto \& Alberts (1970). Phages were then purified on $\mathrm{CsCl}$ gradients as described by Maniatis et al. (1982).

Electron microscopy. A drop of phage BFK20 purified as described above was placed on a copper grid coated with Formvar and stained with $2 \%(\mathrm{w} / \mathrm{v})$ uranyl acetate for $30-40 \mathrm{~s}$. The microscope used was a Tesla (Brno, CSFR) model BS540.

$S D S$ - PAGE. The purified phage proteins were suspended in $60 \mathrm{mM}$ $\mathrm{Tris} / \mathrm{HCl}$ (pH 6.8) containing $5 \%$ (v/v) $2-\beta$-mercaptoethanol and $2 \%$ (w/v) SDS, boiled at $100^{\circ} \mathrm{C}$ for $5 \mathrm{~min}$, and applied to a $10 \%(\mathrm{w} / \mathrm{v})$ polyacrylamide gel (Laemmli, 1970). After migration of proteins, the 
gels were stained either with Coomassie brilliant blue (Laemmli, 1970) or with silver (Oakley et al., 1980).

Extraction of phage DNA. This was done as described for bacteriophage by Maniatis et al. (1982).

Plasmid DNA purification and DNA manipulation. Plasmid DNAs from $E$. coli were isolated by the method of Birnboim \& Doly (1979). The reaction conditions for the enzymes used were described by Maniatis et al. (1982). For shotgun cloning procedures, $0.05 \mathrm{mg}$ of vector pJUP05 linearized with BamHI and treated with calf intestine phosphatase plus $0.5 \mathrm{mg}$ of partially Sau3A-digested bacteriophage DNA were ligated for $16 \mathrm{~h}$ in $10 \mu \mathrm{l}$ at $14^{\circ} \mathrm{C}$ with $0.1 \mathrm{U}$ of T4 DNA ligase (Maniatis et al., 1982).

Protoplasts of $C$. glutamicum RM3 were transformed with $\mathrm{pJUFt} 3$ by the method of Yeh et al. (1986).

The number of copies of plasmid DNA per chromosome were determined as described by Taylor \& Brose (1988).

DNA hybridization analysis. The XbaI-KpnI DNA fragment from plasmid pJUF1 carrying promoter activity and the KpnI-PvuII fragment carrying the transcription-terminator were labelled with $\left[\alpha^{-32} \mathrm{P}\right] \mathrm{dCTP}$ by the nick-translation procedure of Rigby et al. (1977) and used as a probe for Southern hybridization analysis. Phage BFK20 DNA $(0.5 \mathrm{mg})$, both digested with restriction nucleases and not digested, was separated in a $0.8 \%$ agarose gel. After electrophoresis, DNA was transferred onto a nitrocellulose membrane by the procedure of Southern (1975). Prehybridization, hybridization and stringent washing procedures were as described by Maniatis et al. (1982).

NPTII assay. Neomycin-phosphotransferase (NPTII) was assayed by the method of Cabanes-Bastos et al. (1989). C. glutamicum and E. coli were grown in $100 \mathrm{ml}$ of $\mathrm{LB}$ medium to $\mathrm{OD}_{570}=0.8$ and 0.6 respectively. The cells were harvested and the pellets were washed and suspended in $10 \mathrm{~mm}$-Tris $/ \mathrm{HCl}, \mathrm{pH} 7 \cdot 5,10 \mathrm{~mm}-\mathrm{MgCl}_{2}, 25 \mathrm{~mm}-\mathrm{NH}_{4} \mathrm{Cl}$, $0.6 \mathrm{mM}$-mercaptoethanol. After sonication, the crude extract was obtained by centrifugation at $100000 \mathrm{~g}$ for $1 \mathrm{~h}$. Crude enzyme was precipitated by addition of $60 \%(w / v)$ ammonium sulphate to the supernatant, collected by centrifugation, dissolved in the minimum volume of buffer as above, and dialysed against the same buffer. A $10 \mu 1$ volume of this solution was used for assay of NPTII.

\section{Results and Discussion}

\section{Morphology and host spectrum of phage BFK20}

Bacteriophages isolated previously from Brevibacterium and Corynebacterium strains have belonged to Bradley's group B (Bradley, 1967): they have a polyhedral head 40$70 \mathrm{~nm}$ wide and a tail 100-300 $\mathrm{nm}$ long (Hongo et al., 1984; Ozaki et al., 1984; Pátek et al., 1985; Trautwetter et al., 1987a, $b$; Trautwetter \& Blanco, 1988). Phage BFK20 looked, on electron micrographs (Fig. 1), like phages of Bradley's group B, since it has a $50-\mathrm{nm}$-wide polyhedral head and a non-contractile tail $200 \mathrm{~nm}$ long and $10 \mathrm{~nm}$ wide.

Of five strains of brevibacteria examined (B. flavum ATCC 21474, B. flavum CCM 251, B. flavum ATCC $21127, B$. lactofermentum BLOB and C. glutamicum ATCC 13032), only $B$. flavum CCM 251 was sensitive to phage BFK20. Titres of about $8 \times 10^{8}$ p.f.u. $\mathrm{ml}^{-1}$ were routinely obtained.

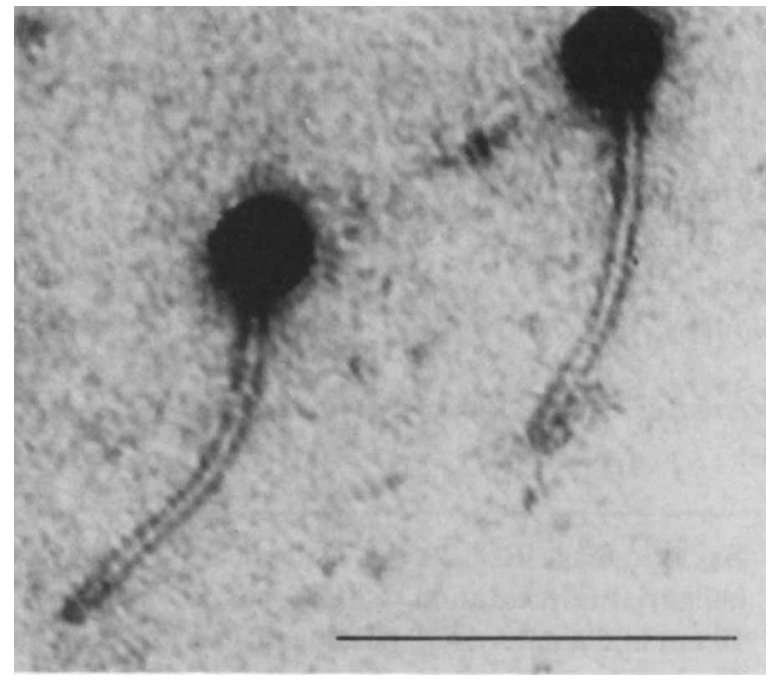

Fig. 1. Electron micrograph of phage BFK20. Bar, $200 \mathrm{~nm}$.

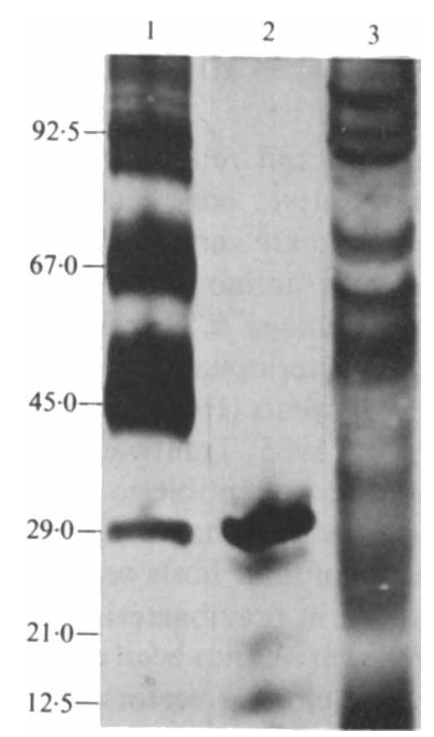

Fig. 2. SDS-PAGE of the structural polypeptides of phage BFK20. The acrylamide gel $(10 \%$, w/v) was stained with silver. Lane 1 , molecular mass markers: phosphorylase $b(92.5 \mathrm{kDa})$, bovine albumin $(67.0 \mathrm{kDa})$, egg albumin (45.0 kDa), carbonic anhydrase $(29.0 \mathrm{kDa})$. Lane 2, molecular mass markers: carbonic anhydrase, $(29.0 \mathrm{kDa})$, trypsin inhibitor $(21.0 \mathrm{kDa})$, cytochrome $c(12.5 \mathrm{kDa})$. Lane 3, purified BFK20.

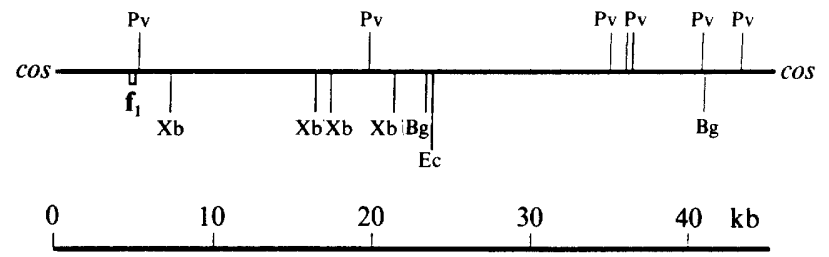

Fig. 3. Restriction map of the phage BFK20 chromosome. Sizes of the restriction fragments are shown in Table 1: Pv, PvuI; Bg, BglII; Ec, $E c o R I ; X b, X b a I$. $f_{1}$, Fragment carrying promoter activity. 

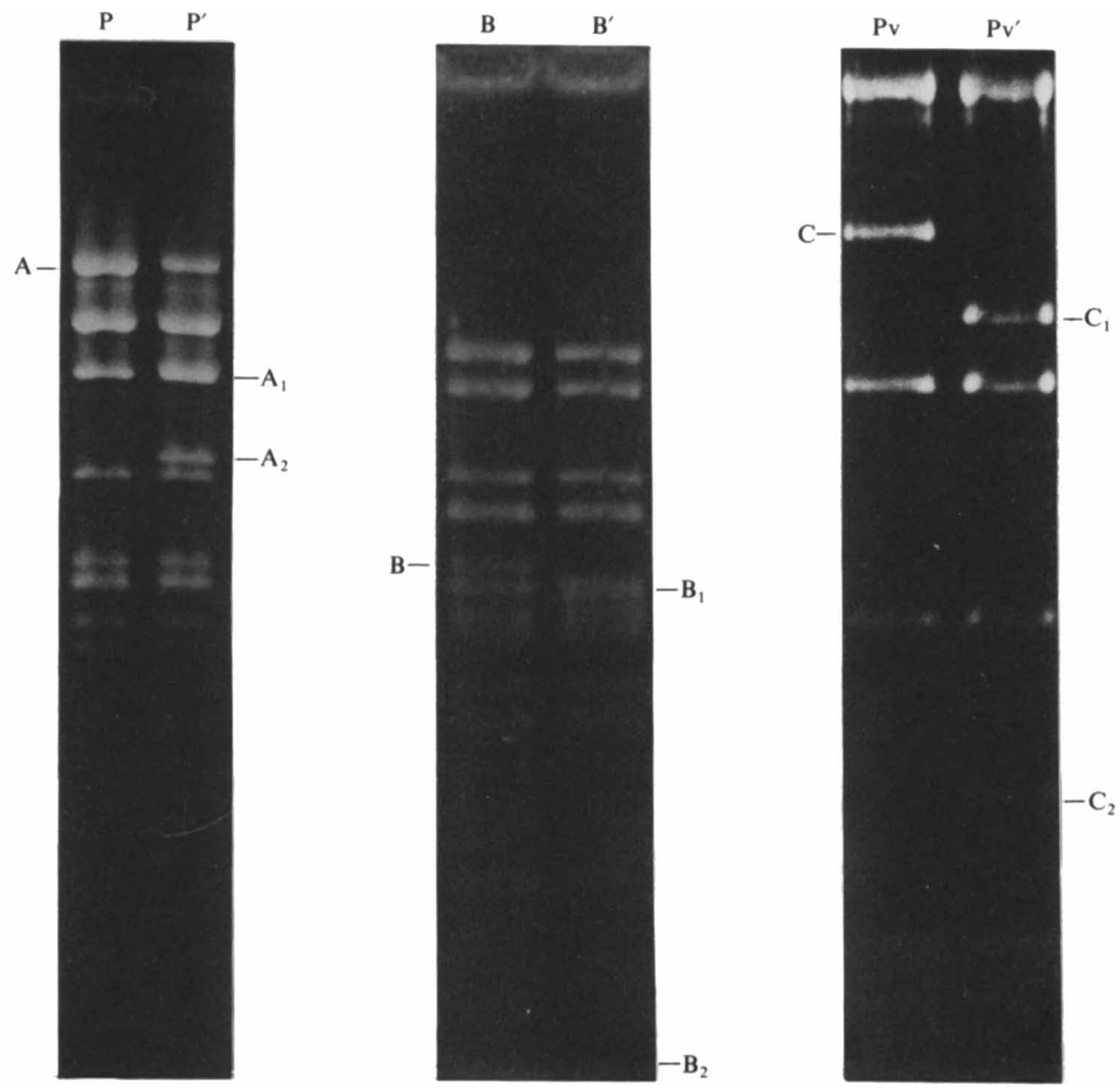

Fig. 4. Mapping of the 'cos' sequence of phage BFK20. Lanes $\mathrm{PP}^{\prime}, \mathbf{B B}^{\prime}$ and $\mathrm{PvPv}$ ' represent BFK20 DNA digested with PstI, BamHI and Pvul, respectively. Samples in lanes $\mathbf{P}, \mathbf{B}$ and $\mathrm{Pv}$ were loaded directly onto an agarose gel; samples in lanes $\mathbf{P}^{\prime}, \mathrm{B}^{\prime}$ and $\mathrm{Pv}^{\prime}$ were loaded after heating for $15 \mathrm{~min}$ at $72{ }^{\circ} \mathrm{C}$ in $6 \%(\mathrm{w} / \mathrm{v})$ sucrose and $44 \mathrm{~mm}$-EDTA, and rapidly cooling on ice. In each case heating produced new fragments $\left(A_{1}, A_{2} ; B_{1}, B_{2} ; C_{1}, C_{2}\right)$, while one restriction fragment $(A, B, C)$ disappeared or was reduced in intensity.

\section{Structural polypeptides of BFK20}

The polypeptides of CsCl-purified phage BFK20 were analysed by SDS-PAGE (Fig. 2). The capsid of phage BFK 20 contained polypeptides with molecular masses of $22 \cdot 0,25 \cdot 1,33 \cdot 3,50 \cdot 1,58 \cdot 4,68 \cdot 1,85 \cdot 7,92 \cdot 5$ and $108 \cdot 0 \mathrm{kDa}$. The $50 \cdot 1 \mathrm{kDa}$ protein appeared in very high amounts, apparently being the constituent of a major structural phage component(s).

\section{Genome organization of phage BFK20}

The genome of bacteriophage BFK20 is a double stranded DNA molecule with cohesive ends. As determined by electron microscopy of the phage DNA (data not shown) and by summing the sizes of the restriction fragments produced by each of the restriction endo- nucleases the genome size was $44-45 \mathrm{~kb}$. The restriction map of bacteriophage BFK20 DNA was constructed according to the results of (i) the single, double and triple digestion analysis with restriction endonucleases, (ii) partial digestion analysis of BFK20 DNA and (iii) the determination of homology between various single or partially digested BFK20 DNAs and ${ }^{32}$ P-labelled DNA fragments from the same phage. The restriction map of phage BFK20 DNA is shown in Fig. 3. The circularization of DNA is apparently a result of annealing of cohesive ends since the circular configuration is unstable and is suppressed by heating in buffered sucrose (Fig. 4). In each of the three restriction digests tested, heating provoked disappearance of one of the restriction fragments $A, B$ or $C$ and gave rise to two new fragments $\left(A_{1}, A_{2} ;\right.$ or $B_{1}, B_{2} ;$ or $\left.C_{1}, C_{2}\right)$, which together accounted for the missing bands. 


\section{Isolation of a phage BFK20 DNA fragment carrying $a$ promoter}

Using a promoter probe vector we isolated DNA fragments carrying promoter activity. Sau $3 \mathrm{~A}$ fragments from phage BFK20. DNA were cloned into plasmid pJUP05 digested with BamHI and dephosphorylated. $E$. coli $\mathrm{HB} 101$ cells were transformed with the ligation mixture. From the positive clones which grew on LB media containing kanamycin $\left(100 \mathrm{mg} \mathrm{l}^{-1}\right)$ we isolated plasmid pJUF1. This plasmid was a derivative of the vector pJUP05 carrying a $0.3 \mathrm{~kb}$ inserted fragment. The strength of fragment $f_{1}$ and the original promoter of $\mathrm{Km}^{\mathrm{R}}$ was determined semi-quantitatively. The relative strength of the promoter was calculated from the minimal inhibitory concentration (MIC) of $\mathrm{Km}$ and the number of copies of the plasmids in cells of $E$. coli $\mathrm{HB}$ 101. The results are shown in Table 1 . The $\mathrm{Km}$ gene from transposon $\mathrm{Tn} 5$ with its own promoter is situated on plasmid pJU2. Each of the two promoters, the original promoter of the $\mathrm{Km}^{\mathrm{R}}$ gene and the promoter from fragment $\mathrm{f}_{1}$ worked effectively in $E$. coli. The highest expression in $E$. coli was achieved by the promoter from fragment $f_{1}$. The localization of fragment $f_{1}$ on the DNA of bacteriophage BFK20 (Fig. 3) was determined using Southern hybridization.

C. glutamicum strain RM3 was transformed with plasmid pJUF1. Only deleted derivatives, bearing a deletion in the $S a l$ fragment of plasmid pJUF1, could be obtained from the transformed clones. These results show structural instability of plasmid pJUF1, probably caused by the influence of the strong promoter situated in front of the $\mathrm{Km}^{\mathrm{R}}$ gene.

\section{Introducing the F1 promoter into C. glutamicum}

It is known from previous work that cloning of strong promoters can be made possible by downstream replacement of a RNA-termination signal (Gentz et al., 1981). Cadenas et al. (1991) and Bartone \& Blanco (1991) have shown that transcription-terminators which work efficiently in $E$. coli do not do so in corynebacteria. For this reason we used as a transcription-terminator donor phage BFK20 DNA. We introduced Sau3A fragments into the $B g l I I$ site upstream of the $\mathrm{Km}^{\mathrm{R}}$ gene. Transformants of C. glutamicum RM3 were selected on BHI plates supplemented with $\mathrm{Cm}\left(8 \mathrm{mg} \mathrm{l}^{-1}\right)$. From clones which grew on LB plates supplemented with $\mathrm{Km}$ ( $70 \mathrm{mg}$ $1^{-1}$ ) but failed to growth on LB plates supplemented with $\mathrm{Km}\left(80 \mathrm{mg} \mathrm{1}^{-1}\right)$, we isolated plasmid pJUFt 3 , which is a derivative of pJUF1 with a $0.2 \mathrm{~kb}$ inserted fragment. Plasmid pJUFt 3 was introduced into $E$. coli $\mathrm{HB} 101$. The MIC of $\mathrm{Km}$ for $E$. coli $\mathrm{HB} 101$ clones harbouring plasmid pJUFt3 decreased from $1000 \mathrm{mg} \mathrm{l}^{-1}$ to $70 \mathrm{mg} \mathrm{l}^{-1}$.
Table 1. Relative strength of promoters in E. coli HB10I

$N$, copies of plasmids per chromosome; $S$, relative strength of promoter $(\mathrm{MIC} / N)$.

\begin{tabular}{|c|c|c|c|c|c|c|c|c|c|c|c|}
\hline \multirow{2}{*}{$\begin{array}{l}\text { E. coli } \mathrm{HB} 101 \\
\text { with plasmid: }\end{array}$} & \multicolumn{9}{|c|}{$\mathrm{MIC}\left(\mathrm{mg} \mathrm{l}^{-1}\right)$ of kanamycin } & \multirow[b]{2}{*}{$N$} & \multirow[b]{2}{*}{$S$} \\
\hline & 50 & 100 & 200 & 300 & 400 & 600 & 700 & 800 & 1000 & & \\
\hline pJUP05 & - & - & - & - & - & - & - & - & - & 40 & 0 \\
\hline pJU2 & + & + & + & + & + & + & + & + & - & 47 & 17 \\
\hline pJUF1 & + & + & + & + & + & + & + & + & + & 38 & $>26$ \\
\hline
\end{tabular}

Table 2. Expression of NPTII (neomycin-phosphotransferase) in $E$. coli and $C$. glutamicum

-, No clones harbouring plasmid pJUF1 were detected.

\begin{tabular}{lcc}
\hline \hline & \multicolumn{2}{c}{ NPTII specific activity $\left(\mathrm{pmol} \mathrm{min} \mathrm{mg}^{-1} \mathrm{mg}^{-1}\right)$} \\
\cline { 2 - 3 } Plasmid & E. coli & C. glutamicum \\
\hline None & 0 & 0 \\
pJUF1 & 210 & - \\
pJUFt3 & 14 & 4.5 \\
\hline \hline
\end{tabular}

The specific activity of neomycin-phosphotransferase in E. coli $\mathrm{HB} 101$ (pJUF1, pJUFt3) and C. glutamicum(pJUFt3) is shown in Table 2.

Hybridization experiments located terminator T3 on a $9.1 \mathrm{~kb} X b a \mathrm{I}$ fragment of the phage restriction map.

Our data show that sequences recognized by the RNA polymerase of corynebacteria as promoters and transcription-terminators work in both corynebacteria and $E$. coli. However, promoter F1 seems to be stronger in $C$. glutamicum than in E. coli, indicating certain differences in the recognition specifity of $E$. coli and corynebacterial RNA polymerase.

We wish to thank Dr K. Bederková for electron micrographs of phage particles, and Dr A. Puhler for providing us with $C$. glutamicum strains ATCC 13032 and RM3.

\section{References}

Adams, M. H. (1959). Bacteriophages. New York: Interscience Publishers.

Barák, I., Koptides, M., Jucovič, M., Šišova, M. \& Timko, J. (1990). Construction of a promoter-probe shuttle vector for Escherichia coli and brevibacteria. Gene $95,133-135$.

BIRNBOIM, H. C. \& DOLY J. (1979). A rapid alkaline extraction procedure for screening recombinant plasmid DNA. Nucleic Acids Research 7, 1513-1523

Bartone, N. \& BlanCo, C. (1991). Improved vectors for transcriptional signal screening in corynebacteria. FEMS Microbiology Letters 84, 97-102. 
BOYeR, H. W. \& Roulland-Dussoix, D. (1969). A complementation analysis of the restriction and modification of DNA in Escherichia coli. Journal of Molecular Biology 41, 459-472.

BRADLEY, D. E. (1967). Ultrastructure of bacteriophages and bacteriocins. Bacteriological Reviews 31, 230-314.

Cabanes-Bastos, E., Day, G. A. \& Lichtenstein, P. C. (1989). A sensitive and simple assay for neomycin phosphotransferase II activity in transgenic tissue. Gene 77, 169-176.

Cadenas, F. R., Martin, F. J. \& Gil, A. J. (1991). Construction and characterization of promoter-probe vectors for corynebacteria using the kanamycin-resistance reporter gene. Gene 98, 117-121.

Gentz, R., Langner, A., Chang, A., Cohen, S. \& Bujard, H. (1981). Cloning and analysis of strong promoters is made possible by the downstream placement of a RNA termination signal. Proceedings of the National Academy of Sciences of the United States of America 78, 4936-4940.

Hongo, M., OKI, T. \& OGata, S. (1972). Phage contamination and control. In The Microbial Production of Amino Acids, pp. 67-90. Edited by K. Yanada, S. Kinoshita, T. Tsunoda \& K. Aida. Tokyo: Kodansha.

LAEMMLI, U. K. (1970). Cleavage of structural proteins during the assembly of the head of bacteriophage T4. Nature, London 227,680 685.

Maniatis, T., Fritsch, E. F. \& SambrooK, J. (1982). Molecular Cloning, a Laboratory Manual. Cold Spring Harbour, NY: Cold Spring Harbor Laboratory.

Miwa, K., Matsui, K., Terabe, M., Ito, K., Ishida, M., Takagi, H., NAKAMORI, S. \& SANO, K. (1985). Construction of novel shuttle vectors and a cosmid vector for the glutamic acid-producing bacteria Brevibacterium lactofermentum and Corynebacterium glutamicum. Gene 39, 281-286.

OAKLEY, B. R., KIRSCH, D. R. \& MORRIS, N. R. (1980). A simplified ultrasensitive silver stain for detecting proteins in polyacrylamide gels. Analytical Biochemistry 105, 361-363.

Ozaki, A., Katsumata, R., Oka, T. \& FuRUYA, A. (1984). Transfection of Corynebacterium glutamicum with temperate phage OCG1. Agricultural and Biological Chemistry 48, 2597-2601.
Pátek, M., Ludvík, J., Benada, O., Hochmannová, J., Nešvera, J., KRUMPHANZL, V. \& BuČKo, M. (1985). New bacteriophage-like particles in Corynebacterium glutamicum. Virology 140, 360-363.

Rigby, P. V., DieckmanN, M., Rhodes, C. \& Berg, P. (1977). Labelling deoxyribonucleic acid to high specific activity in vitro by nick translation with DNA polymerase I. Journal of Molecular Biology 113, 237-251.

Santamaria, R., Gil, J. A., Mesas, J. M. \& Martin, J. F. (1984). Characterization of an endogenous plasmid and development of cloning vectors and transformation system in Brevibacterium lactofermentum. Journal of General Microbiology 130, 2237-2246.

SOUTHERN, E. M. (1975). Detection of specific sequences among DNA fragments separated by gel electrophoresis. Journal of Molecular Biology 98, 503-517.

TAYLOR, D. E. \& Brose, E.C. (1988). Modified Birnboim-Doly method for rapid detection of plasmid copy number. Nucleic Acids Research 16, 9056

Trautwetter, A. \& BlanCo, C. (1988). Isolation and preliminary characterization of twenty bacteriophages infecting either Brevibacterium or Arthrobacter strains. Applied and Environmental Microbiology 54, 1466-1471.

Trautwetter, A., Blanco, C. \& Sicard, A. M. (1987a). Structural characteristics of the Corynebacterium lilium bacteriophage CL31. Journal of Virology 61, 1540-1545.

Trautwetter, A., Blanco, C. \& Bonnassie, S. (1987b). Characterization of the corynebacteriophage CG33. Journal of General Microbiology 133, 2945-2952.

Yamamoto, K. R. \& AlbeRTS, B. M. (1970). Rapid bacteriophage sedimentation in the presence of polyethylene glycol and its application to large scale virus purification. Virology 40, 734744.

Yeh, P., Oreglia, J., Prévots, F. \& Sicard, A. M. (1986). Shuttle vector system for Brevibacterium lactofermentum. Gene 47, 301306.

Yoshinaga, F. \& NAKamori, S. (1983). Amino acids: Biosynthesis and Genetic Regulation. Edited by K. M. Herman \& R. L. Somerville. Reading, MA: Addison Wesley. 